\title{
Research on Demand for Bus Transport and Transport Habits of High School Students in Žilina Region
}

\author{
Vladimír Konečný $^{1 *}$, Róbert Berežný ${ }^{1}$, František Petro $^{1}$ and Martina Trnovcová ${ }^{1}$ \\ ${ }^{1}$ University of Žilina, Faculty of Operation and Economics of Transport and Communication, \\ Department of Road and Urban Transport, Univerzitná 1, 01026 Žilina, \\ Slovak Republic; Email: vladimir.konecny@fpedas.uniza.sk, robert.berezny@fpedas.uniza.sk, \\ frantisek.petro@fpedas.uniza.sk
}

\section{*Corresponding Author: Vladimír Konečný}

\begin{abstract}
The paper deals with the analysis of demand for bus transport to examine determinants of demand and practices of high school students based on survey of their transport habits in Žilina Region. Transport habits of students are individual and variable in time. This group of passengers is dependent on public passenger transport services because of their travelling to schools. Significant part of demand for public passenger transport is also formed by this this group of passengers. The knowledge of student's transport habits may help in process of adaptation of offering and quality of transport serviceability what may subsequently stabilize demand for public passenger transport.
\end{abstract}

Keywords: Demand, transport, students, determinants of demand, transport habits

\section{Introduction}

Transport demand is characterized as a secondary demand. It derives results from the habits of the population and the demand for goods and services.

Measure of the impact of individual factors of demand may vary. It is specific for each individual area in the Slovak Republic, in which the public passenger transport services are provided. Impact of factors is changed in relation to the temporal evolution of their values [1].

Žilina self-governing region is situated in the northwest of Slovakia and is the third largest region in the Slovak Republic. The region is geographically divided into five regions and 11 districts. A regular bus transport (RBT) carried by the two companies provides a basis operator of this extensive area. Figure 1 shows a map of the Žilina self-governing region with the position of its districts [2]. 


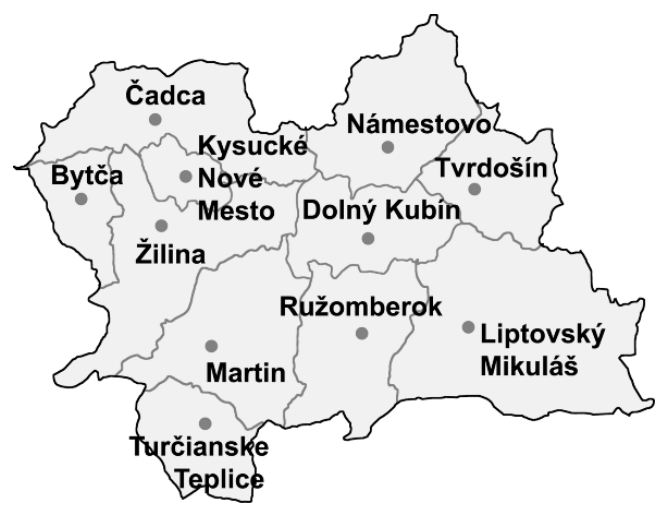

Fig. 1 Districts in the Žilina region and their position. Source: [2]

\section{Analysis of Demand for Passenger Transport in Žilina Region and his Determinants}

Demand for transport services is determined by several factors at the same time. The impact of these factors varies. The impacts of the different demand factors also differ according to the groups of passengers who realize the demand for bus transport.

\subsection{Analysis of Demand for Passenger Transport in Slovakia and Žilina Region}

The number of transported passengers may be an indicator of demand. It is available and monitored statistics. Performance of bus services in recent years is significantly decreasing. This applies to all groups of passengers. Also varies greatly proportionality structure of demand in terms of groups of passengers or type of fare.

The number of transported passengers by bus in Slovakia in the ordinary fare reached in 2015 only $36.5 \%$ of the number in 2000 representing a decrease of $63.5 \%$. At the pupils fares decreased demand in the same period to $48.3 \%$. The average annual pace of decrease of demand is $6.5 \%$ ordinary fare, pupil fare $-4.3 \%$.

At the pupils and students demand for passenger transport in 2015 is strongly reflected the impact of the introduction of free fare in rail passenger transport (RPT) in November 2014. Demand for pupil traveling in the bus sector occurred in 2015 towards in 2014 significantly caused by jolting to decrease by $16.3 \%$. [3]

Development and structure of the number of passengers regular bus transport is shown in Figure 2. 


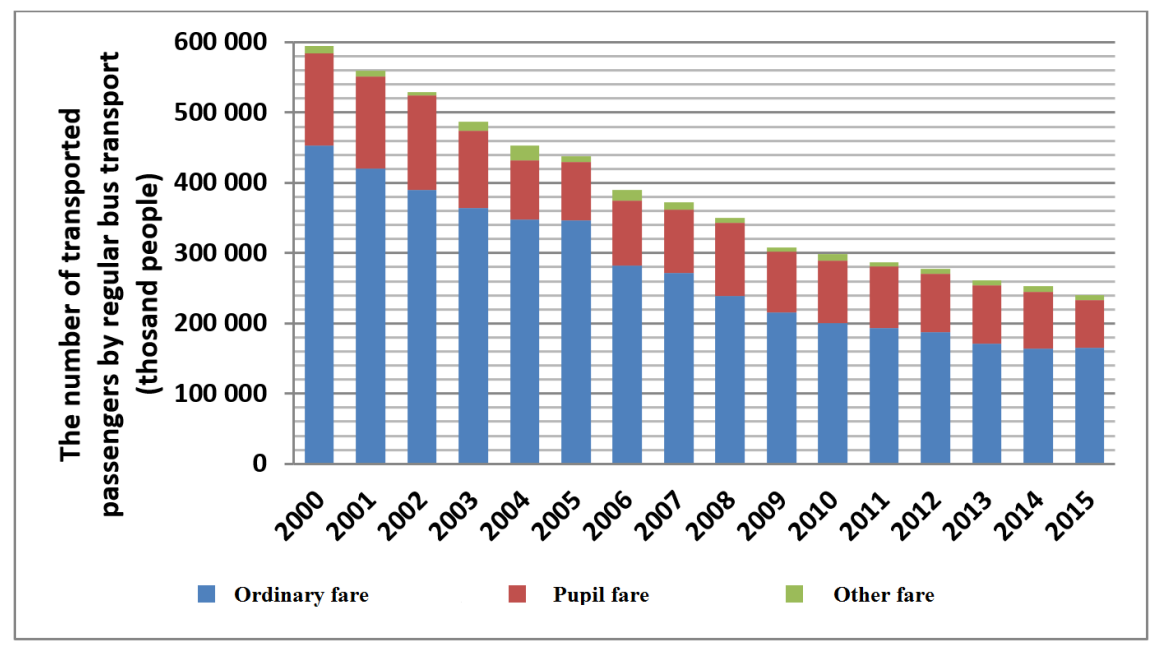

Fig. 2 Development of the number of transported passengers by regular bus transport by type of fare in Slovakia in 2000-2015. Source: authors, based on [4]

Decline in demand for bus transport is offset by the increase performance of individual motorized transport, particularly regarding the number of persons transported per ordinary fare for bus transport. In December 2016 the Statistical Office published the latest data on passenger demand in the Slovak Republic, 2015.

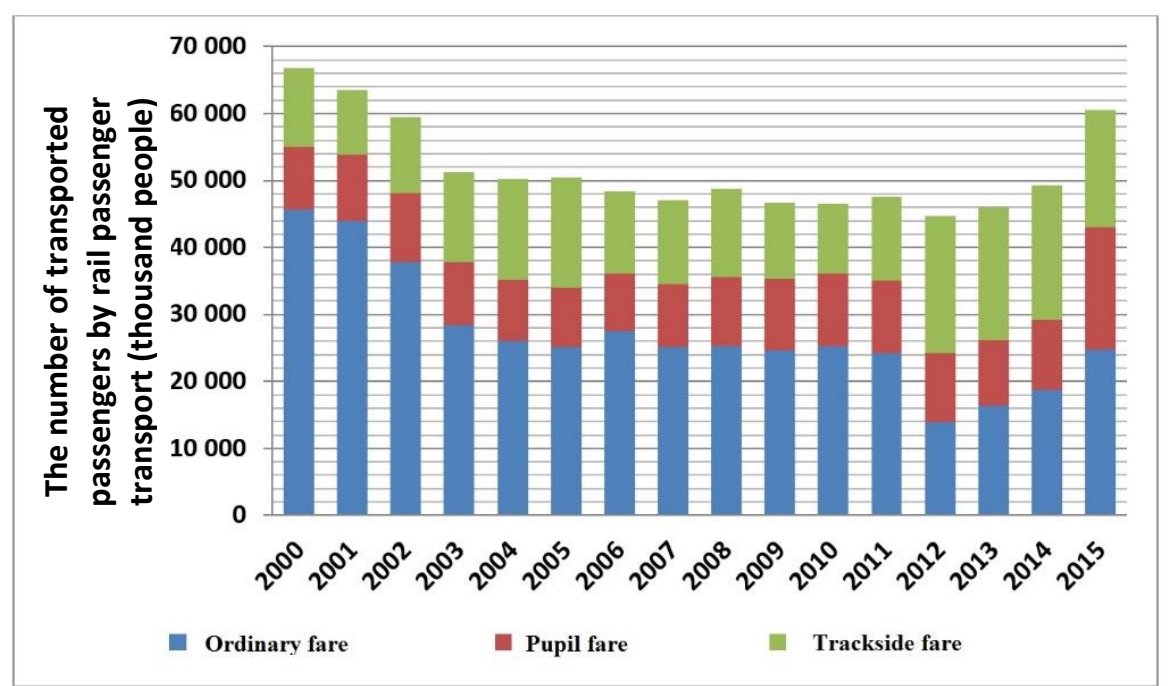

Fig. 3 Development of the number of transported passengers by rail passenger transport by type of fare in Slovakia in 2000-2015. Source: authors, based on [4]

Between 2014 and 2015 there was a significant decrease in the number of persons transported per pupil fares for regular bus transport (-13 197 thous. people), while rail transport was a significant increase in demand of this group of passengers (+7 805 thous. people), see Fig. 2 and 3. These facts confirmed by the findings of the survey the transport habits of secondary school pupils in chapter 2 of this paper.

Negative developments in demand for bus transport also concerns Žilina region. The number of transported passengers per pupil fare in Žilina region reached the 2014 share of $66 \%$ of the number in 2004 a decrease of $34 \%$. The average annual decrease in demand for pupil fare reaches a value of $3.4 \%[4]$. 


\subsection{Analysis of Demographic Changes in the Žilina Region in the Pupil and Student Age}

Demographic changes not only in the Slovak Republic determines passenger demand for passenger transport. Great potential for transport is precisely the group of pupils and students. Their transportation for education depends on the use of public passenger transport. With the decline of their population is decreasing the potential for transporting them. The trend decline in transported passengers per pupil fare is expected to well in the future because of decreasing their number in recent years and there are no significant changes in habits and activities of this group of the population and hence the potential increase their momentum. This development is in pupils and students a natural because they unlike other groups are not able to replace the services of mass transport using passenger car. Fig. 4 shows the evolution of the population aged 6-14 years (primary school pupils) and 15-19 years (secondary school students) in the Žilina region [4,5].

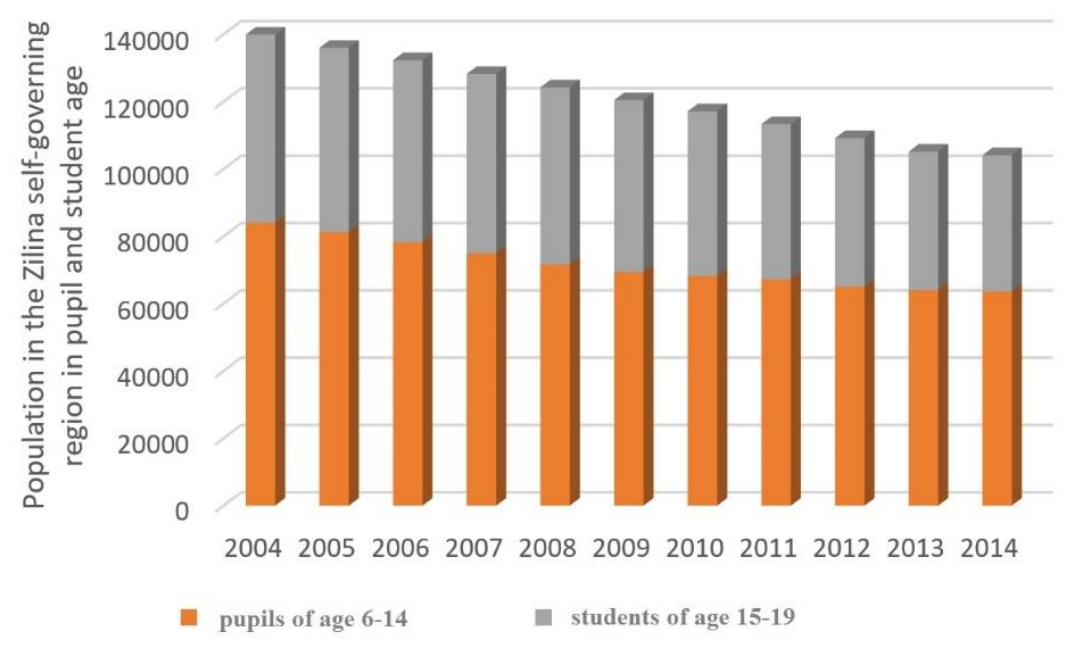

Fig. 4 The development of the population aged 6-14 and 15-19 years in the Žilina region in the period 2004-2014. Source: authors, based on [4]

The coefficient of correlation between the total number of passengers transported per pupil and student fares in bus transport and the population aged 16-19 years in the Žilina region reaches a value of 0.947 it is a strong direct dependence.

\subsection{Analysis of Prices Development Pupil Fare in the Suburban Bus Transport in the Žilina Region}

The price for the transport of suburban bus transport is dependent on the transport distance and the type of fare. Table 1 shows the calculated average unit price of the Student fare $(€ /$ passengerkilometers) paid in cash and the transport card. The average unit price is determined as the average of the values fixed fare for each tariff zone in terms of price quotations governing fare in the suburban bus transport between 2005 and 2015. For calculation was used relation (1):

$$
\mathrm{f}_{\mathrm{pk}}=\mathrm{t} / \mathrm{TZ},[€ / \text { passenger-kilometers }]
$$


where: $f_{p k}$ is fare in [€/ passenger-kilometers]; $t$ is the tariff of travel in the respective tariff zone; $T Z a$ is the average of the lower and upper limit tariff zone $[\mathrm{km}]$.

The values of the average unit price of the student fare in cash and the transport cards are shown in Table 1. By 2012 the price has upward trend since 2012 the price has not changed see figure 5. Traffic cards were in suburban bus transport in Žilina established in 2008.

Table 1 The values of the average unit price of the student fare ( $€$ / passenger-kilometers) paid in cash and the transport cards in the years from 2005 to 2015 in Žilina region. Source: authors

\begin{tabular}{|c|c|c|c|c|c|c|c|c|c|c|c|}
\hline Years & 2005 & 2006 & 2007 & 2008 & 2009 & 2010 & 2011 & 2012 & 2013 & 2014 & 2015 \\
\hline $\begin{array}{c}\text { Average } \\
\text { unit price } \\
\text { cash } \\
\text { (€/passkm) }\end{array}$ & 0.02483 & 0.02483 & 0.02846 & 0.03578 & 0.03578 & 0.03874 & 0.04192 & 0.04572 & 0.04572 & 0.04572 & 0.04572 \\
\hline $\begin{array}{c}\text { Average } \\
\text { unit price } \\
\text { transport } \\
\text { card } \\
(€ / \text { passkm) }\end{array}$ & - & - & - & 0.02915 & 0.02915 & 0.03429 & 0.03747 & 0.04079 & 0.04079 & 0.04079 & 0.04079 \\
\hline
\end{tabular}

The average rate of increase in the average unit price per pupil fare in suburban bus transport in Žilina region paid in cash reaches a value of $5.71 \%$ and fare paid by transport card represents a value of $4.95 \%$.

The application of correlation coefficient to assess the relationship between the number of traveled passengers for pupil fare and the average unit price for the discounted fares paid in cash amounts coefficient value of -0.950 . Fare paid by transport card achieves a coefficient value of 0.935. In both cases, the strong indirect dependency.

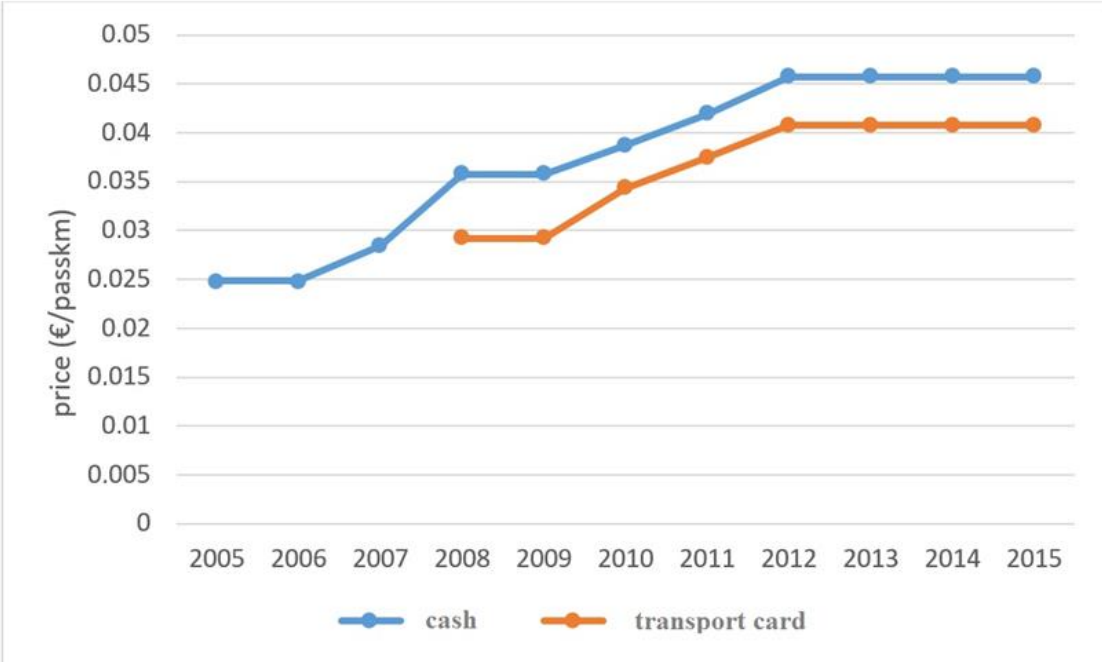

Fig. 5 Development of the average unit price of the student fares paid in cash and the transport card in suburban bus transport in Žilina region. Source: authors 


\subsection{Analysis of Development the Number of Pupils and Schools in Žilina Region}

Demand for passenger transport for pupils fare is determined mainly by the number of pupils and students of primary and secondary schools. The potential demand, pupils and students realize the demand for public passenger transport (PPT) as a derived demand related to the demand for education. The level of demand is also affected by the number and location of educational institutions. Table 2 gives an overview of number of pupils in primary and secondary schools and overview of the number primary and secondary schools in Žilina region between 2003 and 2015. Due to unfavorable demographic development, there was a decrease in the number of primary and secondary schools, raising the need for rationalization of a network of primary and secondary schools.

Table 2 The number of pupils and students of primary and secondary schools and the number of primary and secondary schools in the Žilina region in 2003-2015. Source: authors, based on [6]

\begin{tabular}{|c|c|c|c|c|c|c|c|c|c|c|c|c|c|}
\hline Years & 2003 & 2004 & 2005 & 2006 & 2007 & 2008 & 2009 & 2010 & 2011 & 2012 & 2013 & 2014 & 2015 \\
\hline \multicolumn{14}{|c|}{ Number of pupils and students } \\
\hline Number of pupils & 82559 & 79791 & 76720 & 73742 & 69994 & 66770 & 64767 & 62977 & 61760 & 60587 & 59975 & 59301 & 58934 \\
\hline Grammar school students & 12820 & 13092 & 13490 & 13635 & 13876 & 13631 & 13020 & 12592 & 12200 & 11593 & 11061 & 10714 & 10438 \\
\hline Conservatoire students & - & $\cdot$ & $\cdot$ & - & - & 242 & 245 & 250 & 250 & 256 & 245 & 225 & 231 \\
\hline Secondary professional school students & - & - & - & - & - & 29091 & 28545 & 27138 & 25652 & 24099 & 22767 & 21719 & 20992 \\
\hline Grouped secondary school students & 9229 & 10143 & 10857 & 10594 & 12772 & - & - & - & - & - & - & - & - \\
\hline Secondary vocational students & 11865 & 11559 & 10839 & 10789 & 10331 & - & - & - & - & - & - & - & - \\
\hline Secondary professional and conservatoire students & 10583 & 10024 & 9010 & 8897 & 6422 & - & - & - & - & - & - & - & - \\
\hline Number of students & 44497 & 44818 & 44196 & 43915 & 43401 & 42964 & 41810 & 39980 & 38102 & 35948 & 34073 & 32658 & 31661 \\
\hline Number of pupils and students & 127056 & 124609 & 120916 & 117657 & 113395 & 109734 & 106577 & 102957 & 99862 & 96535 & 94048 & 91959 & 90595 \\
\hline \multicolumn{14}{|c|}{ Number of elementary and secondary school } \\
\hline Number of elementary school & 278 & 276 & 275 & 272 & 272 & 270 & 271 & 268 & 268 & 266 & 262 & 257 & 256 \\
\hline Number of grammar school & 27 & 28 & 28 & 28 & 29 & 28 & 28 & 29 & 29 & 29 & 30 & 30 & 30 \\
\hline Number of conservatoire & - & - & - & - & - & 1 & 1 & 1 & 1 & 1 & 1 & 1 & 1 \\
\hline Number of secondary professional school & - & - & - & - & - & 64 & 65 & 64 & 64 & 63 & 62 & 61 & 62 \\
\hline Number of 'grouped' secondary school & 13 & 16 & 17 & 17 & 21 & - & - & - & - & - & - & - & - \\
\hline Number of sec.prof.school and conser. & 36 & 33 & 33 & 36 & 32 & - & - & - & - & - & - & - & - \\
\hline Number of secondary vocational school & 33 & 27 & 24 & 24 & 17 & - & - & - & - & - & - & - & - \\
\hline Number of secondary schools & 109 & 104 & 102 & 105 & 99 & 93 & 94 & 94 & 94 & 93 & 93 & 92 & 93 \\
\hline Number of elementary and secondary school & 387 & 380 & 377 & 377 & 371 & 363 & 365 & 362 & 362 & 359 & 355 & 349 & 349 \\
\hline
\end{tabular}

The application of the coefficient of correlation between the number of pupils and students and the number of passengers reaches the value of 0.965. Coefficient for the number of all schools reaches the value of 0.913 . In both cases, the strong direct dependence, the number of students and schools are determinant of the demand of pupils and students for suburban bus transport.

\subsection{Evaluation of the Impact Factors of Demand for Pupil Fare in Bus Transport in Žilina \\ Region}

For assessment of the relationship between the level of demand and its particular factor, correlation coefficient was used. Table 3 shows the correlation coefficient between the number of transported passengers per pupil fare and determinants of demand in the Žilina region, data of individual indicators are for the period 2008 - 2014. 
Table 3 Relationship of demand and determinants of demand in the Žilina region expressed by the coefficient of correlation. Source: authors

\begin{tabular}{cccccc}
\hline & $\begin{array}{c}\text { Number of } \\
\text { population aged } \\
\text { 16-19 years }\end{array}$ & $\begin{array}{c}\text { The average } \\
\text { unit price -cash }\end{array}$ & $\begin{array}{c}\text { The average unit } \\
\text { price- transport } \\
\text { card }\end{array}$ & $\begin{array}{c}\text { The number } \\
\text { of pupils and } \\
\text { students }\end{array}$ & $\begin{array}{c}\text { Number of } \\
\text { schools }\end{array}$ \\
\hline $\begin{array}{c}\text { The number of } \\
\text { passengers per } \\
\text { pupil fare }\end{array}$ & 0.994 & -0.950 & -0.934 & 0.992 & 0.907 \\
\hline
\end{tabular}

The number of population aged 16-19 years is not only a potential demand for secondary education, but also a significant potential demand for passenger travel by pupil fare. The coefficient of correlation between the number of passengers transported per pupil fare and the Žilina region population aged 16 to 19 years reaches a value of 0.994 , it is a strong direct dependence, almost linear. Price of fare (cash and transport card) is also an important factor, correlation coefficient reaches strong indirect dependency. Given the impact of this factor in case of availability of free fare rail transport for pupils of secondary schools creates the possibility of substitution of bus transport by rail transport.

\section{Survey of Transportation Habits of Secondary School Students in Žilina Region}

The survey was conducted in order to identify the transport habits of secondary school students in the Žilina region. The survey was conducted in relation to the project solution "Strategy for development and building an integrated transport system in the Žilina self-governing region”. The survey was conducted throughout the region [7].

\subsection{Data for the Research}

The research was conducted in 2015 under the auspices of the Žilina Region, on the evaluation of the results was involved University of Žilina. For research was used questionnaire survey. The questionnaire consisted of the identification section and 10 issues relating to the transport habits of secondary school pupils. Due to the extent we not presented design of questionnaire. The focus of the questions mentioned in another part of the article.

In the survey were interviewed 66 secondary schools in 11 districts of the Žilina region with a request to fill out a questionnaire. 52 schools from 10 districts involved for the purpose of survey. It was the secondary schools of the districts Čadca, Kysucké Nové Mesto, Žilina, Námestovo, Orava, Dolný Kubín, Martin, Turčianske Teplice, Ružomberok and Liptovský Mikuláš. The survey is not involved secondary schools in the district Bytča.

Overall, in the survey, 5191 questionnaires were completed and returned. 5027 of questionnaires were useful for processing and evaluating. The actual questionnaire consisted of 10 questions designed to transport habits of secondary school pupils. 
Processing of the questionnaires was implemented by the software application Microsoft Office Access. Microsoft Access is designed to work with databases. The evaluation was conducted for each district separately:

- for students who commute to secondary school every-day from the place of residence,

- for students who commute to secondary school from college [7].

\subsection{Research Methodology and its Application}

Because of the high range of results we present in this paper results for secondary schools in the district of Žilina. It is the largest district in the Žilina region which is also a major transport hub Žilina. In the district of Žilina occurs on secondary schools from the place of residence of many pupils from the district of Žilina (64\%) of district Čadca and Bytča (by 9\%) and the district Kysucké Nové Mesto (7\%). The rest are other districts [8-10].

\subsubsection{Mode of Transport Used to Travel from Place of Residence to School in the Žilina Region}

The proportion of students using different modes of transport to commute from place of residence to the school district of Čadca (CA), Bytča (BY), Kysucké Nové Mesto (KNM) and Žilina (ZA) is shown in Fig. 6. It was possible to identify several mode of transport. Students who are commuters from district of Bytča used most suburban bus, the proportion of use of rail transport is significantly lower. This is due to differences in the availability of both modes and the eccentric position of the station in Bytča. Student commuters from Čadca and Kysucké Nové Mesto most used rail. Students from the district Žilina most used suburban bus transport and mass urban transportation.

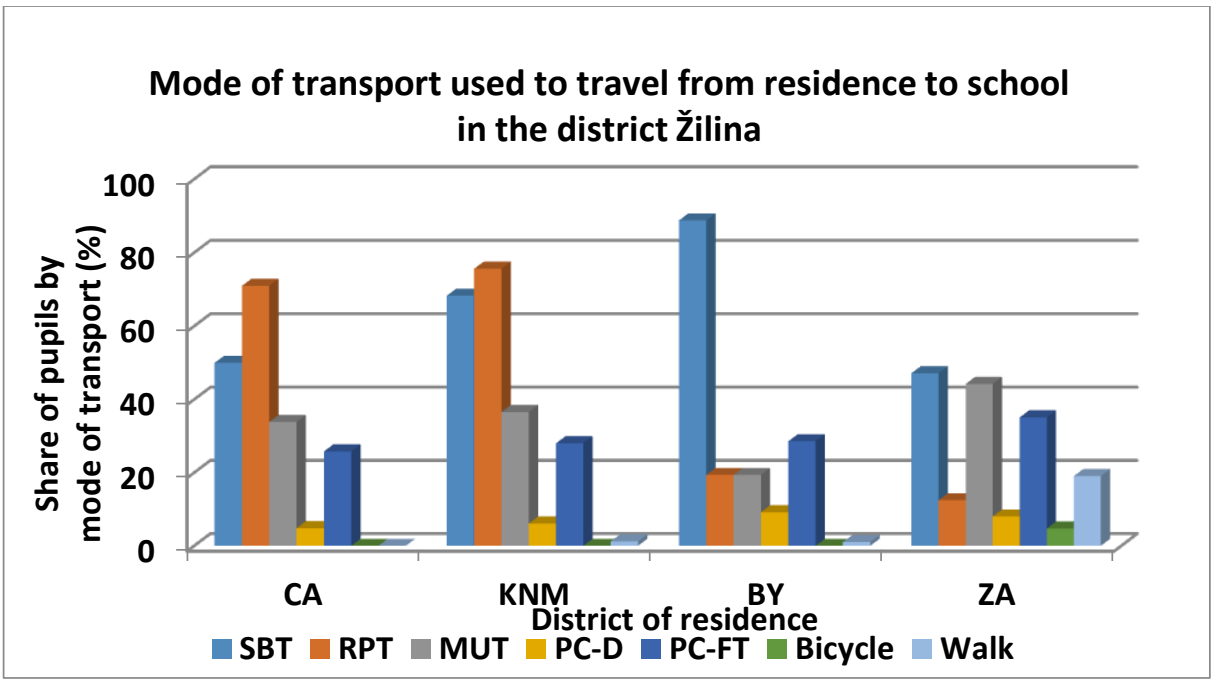

Fig. 6 Mode of transport used to travel from residence to school in the Žilina region. Source: authors

Comments: SBT - suburban bus transport, RPT - rail passenger transport, MUT - mass urban, transport, PC-D - use the personal car as a driver, PC-FT-use the personal car as a fellow traveler. 


\subsubsection{Mode of Transport Used to Travel from School in the Žilina Region to the Place of Residence (back)}

The proportion of students using different modes of transport to commute from school to the place of residence in the district of Čadca (CA), Bytča (BY), Kysucké Nové Mesto (KNM) and Žilina (ZA) is shown in Fig. 7. Proportionality used modes of transport when traveling from school is significantly similar (not identical) to proportionality journeys to school (chapter 3.2.1).

Research has found differences in the balance of traveling secondary school pupils as fellow travelers in passenger car (OA-S). The proportion of pupils passengers in a passenger car as fellow travelers is greater in the morning on the way to school as in the afternoon road from school. The difference between morning and afternoon traveling OA-S at pupils from district Čadca is 6 percentage points (to school 25\%, of schools 19\%) of the district Bytča 6 percentage points (to school 29\%, of schools 23\%) of the district Kysucké Nové Mesto 2 percentage points (28\% to school, from school 26\%) and Žilina district 7 percentage points (35\% to school, from school 28\%). Most probably it is related to the common use personal car family members to travel to school and work at the same or similar time the start of teaching and job performance $[11,12]$.

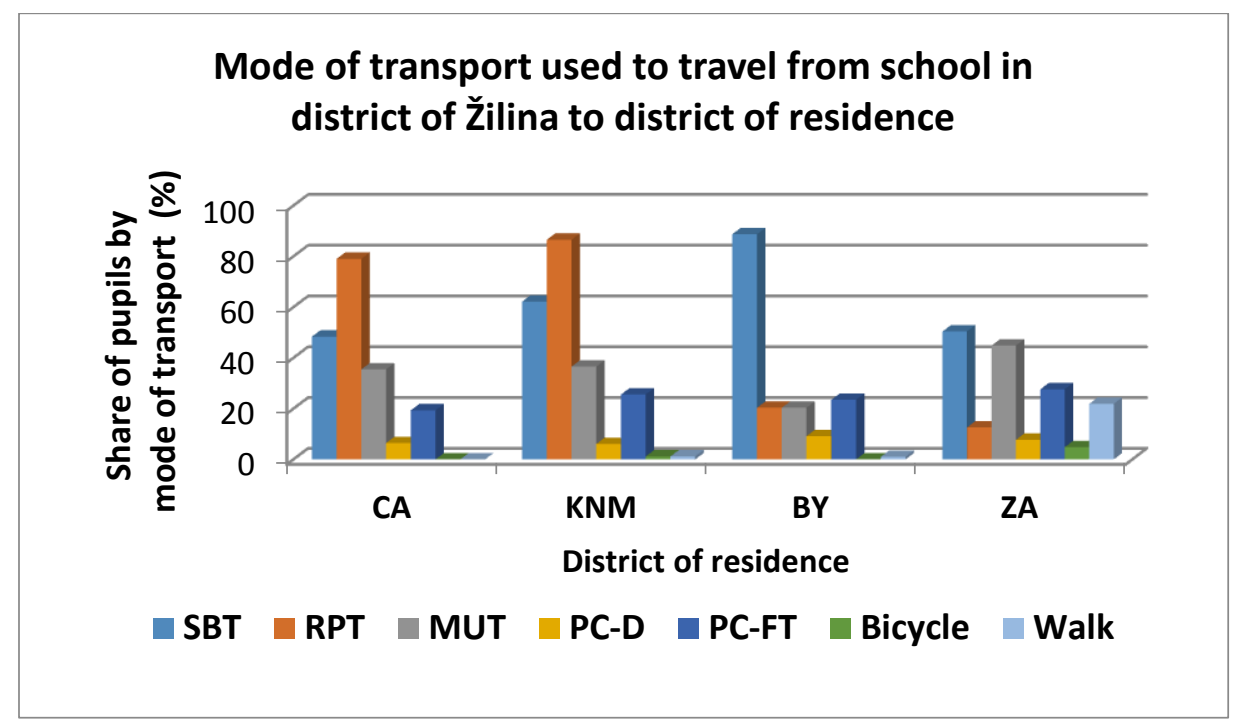

Fig. 7 Mode of transport used to travel from school in the Žilina region to the place of residence. Source: authors

\subsubsection{Impact of the Introduction of Free Fare Transport in Rail Passenger Transport to the Demand for Passenger Transport}

The aim of the research was also the identification group of secondary school students who began using rail transport after introduction free fare transport 17.11.2014. The findings are presented in Figure 8. Increase the proportion of high school students using rail passenger services by introducing free fare transport is most pronounced among students residing in the districts of Čadca and Kysucké Nové Mesto. These are the districts dominated by the use of rail passenger transport. 


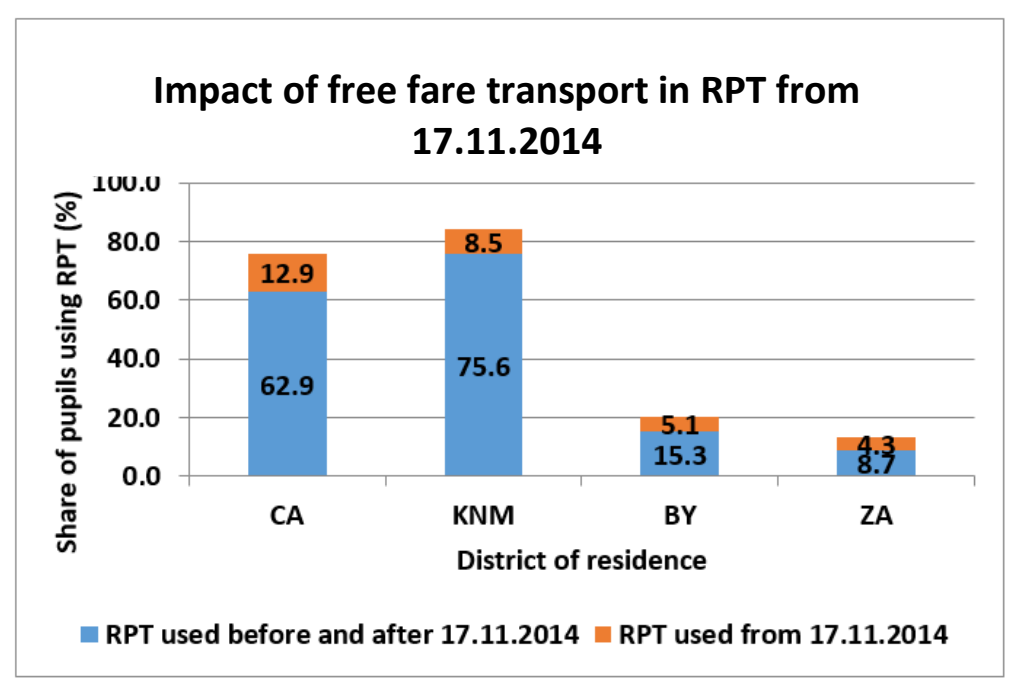

Fig. 8 The use of rail transport by high school students before and after the introduction of free fare transport. Source: authors

\subsubsection{The Importance of Factors of Demand for Public Passenger Transport for Secondary School Students}

The subject of research was also to select factors of demand for secondary school students and determine their average weights of importance. For the evaluation, point scale from 0 to 3 points, 0 - unimportant, 3 - the highest importance was used. Values of the importance of each factor demand are shown in Fig. 9. The most important factor of demand for students is frequency of connections and speed of transport, at least an important impact transport operations on the environment $[13,14]$.

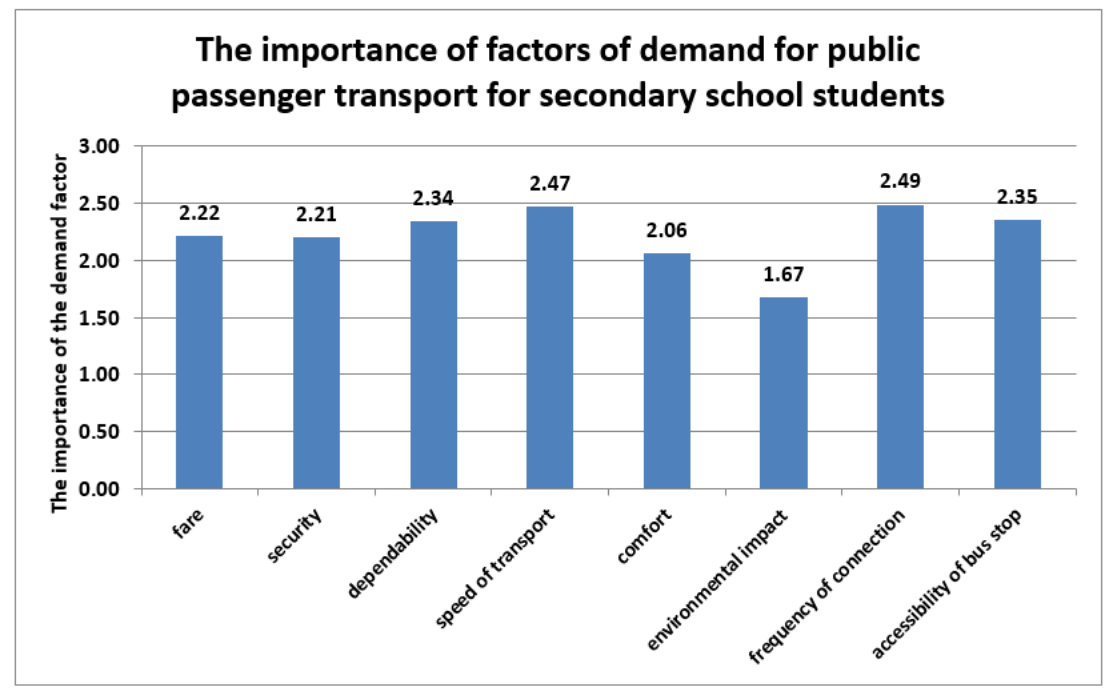

Fig. 9 Values of the importance factors of demand for secondary school students in the Žilina region. Source: authors

\subsubsection{Travel Time to School from the Place of Residence}

The research was also aimed to finding the time duration of travel to school from the place of residence, including delays. It is one of the most important quality criteria. The findings are 
important in the implementation of an integrated transport system (ITS). A passenger expect on the ITS building in abroad especially shortening of time transportation. Fig. 10 shows the various time intervals duration of the transport of specific districts in secondary schools in the district Žilina them and the corresponding percentages of students. Fig. 10 shows that pupils' commuters from the district Kysucké Nové Mesto and Bytča, most often takes 31 to 60 minutes. Students commuter district of Čadca commute almost narovnako at intervals of 31-60 minutes and over 60 minutes. Pupils commuters from the district Žilina most often takes 16 to 30 minutes.

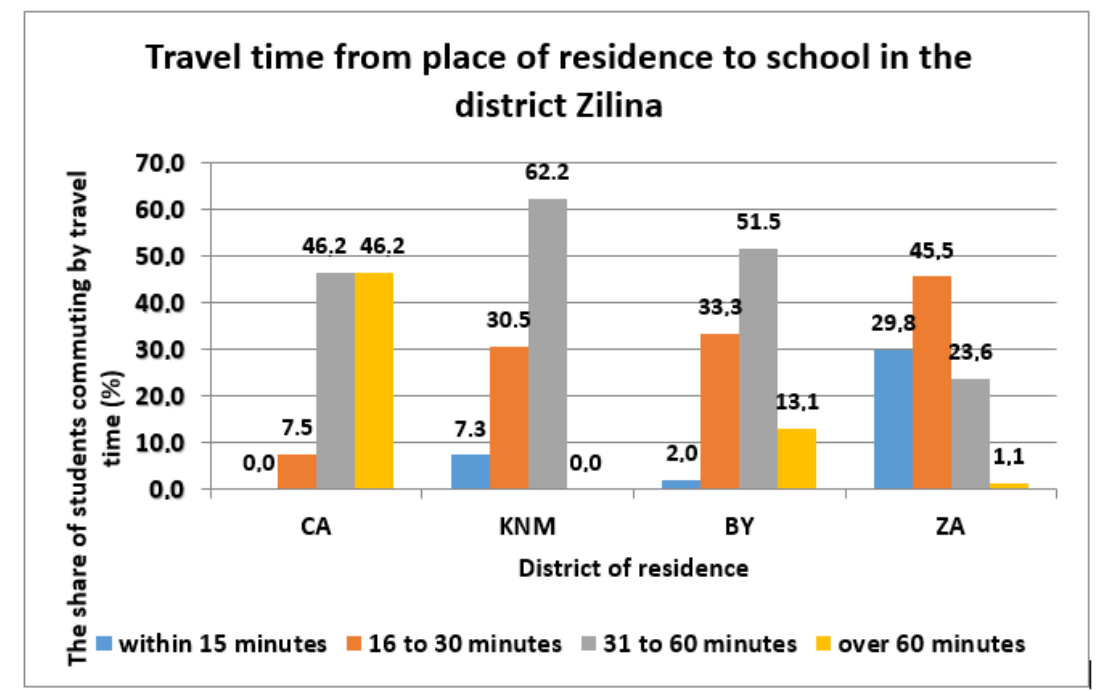

Fig. 10 The share of students commuting from specific districts of residence in the secondary schools in the Žilina region by travel time. Source: authors

\section{Conclusion}

Demographic developments, changes in population structure and settlement structure also affect qualitative parameters of transport serviceability, as well as qualitative parameters provided of transport services in the field of suburban bus transport. For the purpose of slowing the rate of decline in demand in the future it will be necessary to apply only ex post approach based on past demand and the factors, but also a preventive approach (targeted marketing) in relation to actual and potential users of the transport system. This allows the use of existing or employment of new information technologies in order to identify specific passengers and their transportation habits.

Examination of demand in the future should be also targeted to:

- The transition of the number of passengers (sold travel documents) to the number of specific individuals in the system of public transport and the momentum with aim to link potential demand (population) and the actual demand.

- Exploring and understanding the reasons of departure from the system of public passenger transport or the transition from the use of one mode of transport to another.

- Investigating transportation habits groups of passengers 
- Knowing the impact of quality of service on passenger demand in order to define quality standards for transport services and transport serviceability.

This paper has been developed under support of project: MŠVV̌̌ SR - VEGA č. 1/0143/17 POLIAK, $M .:$ Increasing the competitiveness of Slovak carriers providing transport services in road transport in the common market of the European Union

\section{References}

[1] Konečný, V. (2015). Dopyt po prímestskej autobusovej doprave a jeho determinanty (in Slovak). In Verejná osobná doprava 2015: international conference, Bratislava, Slovak Republic. ISBN 978-80-89565-20-7.

[2] Žilina self-governing region. (2017). Retrieved July 15, 2017, from http://www.regionzilina.sk/.

[3] Konečný, V. \& Gnap, J. (2016). Dopyt po autobusovej doprave v kontexte vlakov "zadarmo" (in Slovak). Transport a logistika, 18(2). ISSN 1338-3809.

[4] Statistical office of the Slovak Republic. (2016). Statistical data. Retrieved August 03, 2017, from http://www.statistics.sk/.

[5] Konečný, V. (2012). Vplyv demografického vývoja a štruktúry osídlenia na dopyt po autobusovej doprave (in Slovak). In Verejná osobná doprava 2012: international conference, Bratislava, Slovak Republic. ISBN 978-80-89565-05-4.

[6] Center for Scientific and Technical Information of the Slovak Republic. (2016). Statistical data. Retrieved August 06, 2017, from http://www.cvtisr.sk/.

[7] Strategy for development and building an integrated transport system in the Žilina selfgoverning region. (2015). Project No. 0356/15, University of Žilina, Slovak Republic, responsible investigator: prof. Jozef Gnap, cooperator: assoc. prof. Vladimír Konečný.

[8] Konečný, V. \& Kostolná, M. (2014). Defining standardized quality level in suburban bus transport. Transport and communications: scientific journal, 2. ISSN 1339-5130.

[9] Graham, D., Crotte, A. \& Anderson, A. (2009). A dynamic panel analysis of urban metro demand. Transportation Research Part E: Logistics and Transportation Review, 45, 787-794.

[10] Gnap, J. \& Konečný, V. (2013). Vývoj v autobusovej doprave v SR a vybrané otázky jej konkurencieschopnosti (in Slovak). Transport a logistika, 15(1). ISSN 1338-3809.

[11] Gogola, M., Lokšová, Z. \& Poliaková, B. (2013). Systémy verejnej osobnej dopravy (in Slovak). EDIS, Žilina, Slovak Republic. ISBN 978-80-554-0663-3.

[12] Trnovcová, M. (2016). Výskum dopytu študentov stredných škôl v ŽSK po osobnej doprave (in Slovak). University of Žilina, Diploma thesis. Head of DT: assoc. prof. Vladimír Konečný.

[13] Konečný, V., Poliak, M. \& Poliaková, A. (2010). Ekonomická analýza podniku cestnej dopravy (in Slovak). EDIS, Žilina, Slovak Republic. ISBN 978-80-554-0253-6.

[14] Královenský, J., Gnap, J., Poliak, M. \& Konečný, V. (2008). Ekonomika cestnej a mestskej dopravy, 1 ed. EDIS, Žilina, Slovak Republic. ISBN 978-80-8070-831-3. 